\title{
Knowledge commons: an alternative to proprietary knowledge
}

\section{Marco Ambrosi de la Cadena}

Facultad de Filosofía, Letras y Ciencias de la Educación; Universidad de Cuenca, Cuenca, Ecuador. Autor para correspondencia: marco.ambrosi@ucuenca.edu.ec

Fecha de recepción: 2 de mayo 2017 - Fecha de aceptación: 12 de junio 2017

\begin{abstract}
Intellectual property (IP) has become a crucial factor in scientific knowledge production which is based predominantly on profits and market relations facilitated by Intellectual property rights (IPRs). The result of this production is a 'proprietary knowledge', i.e. an over-patented knowledge which cannot be legally used or produced without the right holder's consent. This work aims to 'reopen' the debate about IP recalling the 'knowledge commons' argument in order to affirm a diversity of ownership definitions, e.g. individual, multiple, collaborative, communitarian and public. The article introduces a brief analyse about the philosophy underlying IP - from authors such as Locke, Hegel and Marx - for a critical appraisal of theoretical and social aspects of knowledge property. The discussion presented about contemporary IP and its consequences for scientific production, includes the study of a biopiracy case involving the Waoranis, an Ecuadorean indigenous community, as an example of the 'over-patenting' of life and knowledge. Thus, in favour of the 'knowledge commons' argument, the paradigmatic case about the donation of the malaria vaccine patent is revised to show that it is possible to organise a scientific production guided by alternative criteria. The methodology used was the critical revision of primary bibliography and academic literature.
\end{abstract}

Keywords: Intellectual property (IP), intellectual property rights (IPRs), proprietary knowledge, overpatenting, knowledge commons.

\section{RESUMEN}

La propiedad intelectual se ha convertido en un factor crucial en la producción de conocimiento científico, que se fundamenta predominantemente en ganancias y relaciones de mercado, mismas que son facilitadas por los derechos de propiedad intelectual. El resultado de esta producción es un "conocimiento propietario", es decir, sobre-patentado que no puede ser legalmente utilizado o producido sin el consentimiento del titular del derecho. El objetivo es "reabrir" el debate sobre la propiedad intelectual con el argumento del "conocimiento común", para así, afirmar una diversidad de definiciones de propiedad, por ejemplo: individual, múltiple, colaborativa, comunitaria y pública. El artículo presenta un breve análisis sobre la filosofía subyacente a la propiedad intelectual - con la revisión de autores como: Locke, Hegel y Marx - para evaluar críticamente los aspectos teóricos y sociales de la propiedad del conocimiento. La discusión sobre la propiedad intelectual actual y sus consecuencias en la producción científica, incluye el estudio del caso de biopiratería que afectó a los Waoranis, una comunidad indígena ecuatoriana, como un ejemplo de la vida y el conocimiento 'sobrepatentado'. Así, se presenta en favor del argumento del 'conocimiento común' la revisión del caso paradigmático de la donación de la vacuna contra la malaria, para demostrar que es posible organizar una producción científica guiada por criterios alternativos. La metodología utilizada fue la revisión crítica de bibliografía primaria y de literatura académica.

Palabras clave: propiedad intelectual, derechos de propiedad intelectual, conocimiento propietario, sobre-patentar, conocimiento común. 


\section{INTRODUCTION}

Intellectual property (IP) has become a crucial factor in scientific knowledge production. An analysis of knowledge ownership entails a revision of how science is produced within social structures along history. Currently, knowledge is created within social structures based predominantly on profits and market relations which are facilitated by IP legislation that protects innovation from imitation and robbery through intellectual property rights (IPRs). Nonetheless, that protection also creates a restriction to knowledge conceived as a 'profit source'. IPRs concede to the holder the exclusive control of the production, and distribution of the patented creation. Thus, 'proprietary knowledge' is established as private knowledge which cannot be legally used or produced without the right holder's consent. The whole process of innovation is 'encapsulated' by proprietary knowledge in the form of the invention which is commercialised in the market. This economic mind-set has led scientific production to look for profits in ever-increasing fields and practices.

The restrictions created by IPRs hinder scientific innovation since inventions cannot be accessed nor improved for extended periods. Likewise, IPRs in the long term has favoured an excessive accumulation of knowledge by producers who in turn 'over-patent' their creations in order to guarantee the control and profitability. Consequently, developing countries and producers cannot access to 'overpatented' knowledge without the right holder's permission, causing a technology dependence. Furthermore, developed countries and big knowledge producers have taken advantage of the weaker IP enforcement of developing countries to appropriate genetic resources from their plants, animals and even humans, through a controversial practice known as biopiracy.

Although, proprietary knowledge would seem a recent concept, the debate about knowledge ownership has a long tradition starting with the elaboration of IP legislation in Europe since the $15^{\text {th }}$ century (David, 1994; 2008; May \& Sell, 2006). The article presents, in the first section, an analysis about the philosophy underlying IP (Drahos, 1996), considering arguments from Greek, Roman and Medieval times, but especially from Locke, Hegel and Marx. The arguments and philosophers were selected to examine their influence in contemporary IP and its alternatives; this revision aims to expose the philosophical justification of IP that allows the privatisation and over-patenting of knowledge and life.

In the second section, contemporary IP is discussed considering its consequences for scientific production. Nowadays, IPRs are defined as private rights based on the Lockean argument that property is for the 'industrious' and 'rational'; therefore, the creator receives the reward for his/her inventiveness through IP. Originally, IP was conceived as a balance between private and public interests, however, IP has favoured unequal distribution, monopolies, and market development primarily affecting developing countries. As an example of the unrestricted 'over-patenting' of life and knowledge, the article studies a biopiracy case involving the Waoranis, an Ecuadorean indigenous community, from whom blood samples were taken without their previous and informed consent.

The last section reviews the argument about 'knowledge commons' emphasising its social character. Usually, IP is considered a legal problem ignoring its social, scientific, economic, and bioethical implications. Precisely, the suggestion about knowledge as a 'common good' highlights those implications within the social character of knowledge production whose participants, contents, and methodologies are diverse. Additionally, the case about the donation of the 'malaria vaccine patent' is examined to show that it is possible to organise a scientific production guided by alternative criteria, such as social interest, sustainability, collaboration, availability, accessibility, and transferability. In conclusion, the article suggests that the most important aspect for 'knowledge commons' is that it 'reopens' the debate about IP allowing the construction of diverse ownership definitions.

\section{THE PHILOSOPHY BEHIND INTELLECTUAL PROPERTY}

Although, 'proprietary knowledge' would seem a recent concept the debate about knowledge ownership has a long tradition within the history of knowledge production; just a brief revision of IP history 
demonstrates the progressive and heterogeneous configuration of property over knowledge since the $15^{\text {th }}$ century (David, $1994 \&$ 2008; May \& Sell, 2006). In this section, the philosophical tradition underlying IP is remarked as a starting point for sketching a critique about knowledge ownership. For this purpose, ideas and arguments about property from different times and authors are summarised to assess their influence in contemporary IP and its alternatives. The analysis presented is not only a historical review but a critical appraisal of the theoretical and social aspects of property without which intellectual property rights (IPRs) would not have their current configuration.

\subsection{Greek, Roman and Medieval times}

The Greeks permitted property over land, animals, objects ${ }^{1}$, and even slaves. The main debate concerning property among Greek philosophers was about the characterisation of property and its relationship with community and state. An interesting reflection was made by Aristotle criticising Plato's unified and centralised state in which private property is seen as a conspicuous aspect for social unity. In the Politics Aristotle (1992, p.1263b7) asserts that communal property inhibits the practice of two important virtues "self-restrain and liberality", whereas, private property allows a full expression of the individual and the development of his personality (Hobhouse, 1913).

Conversely, among Romans the debate was exclusively legal about the origin and character of property. Within Roman law, dominium (ownership) was mainly acquired by occupatio of an unappropriated or abandoned thing (res nullius). The dominium applied to land, animals, buildings, artefacts, and even slaves. Two roman categories are of interest for our purposes: a) Res communes which are open to all but not appropriable by any individual such as: air, running water, sea, and seashores (Buckland, 1963) and b) res inventae in litore maris that refers to things discovered (inventio) in a seashore: pearls, gemstones and treasures. These notions of communes and inventio will influence the later theory about IP regarding rights over inventions and knowledge as a commons.

According to the Early Church Fathers, God gave the world to Adam and Eve on behalf of human kind. In this context, private property is the result of human corruption and avarice brought by the fall (Carlyle, 1913; Rashdall, 1913). During the Middle Ages property rights were interpretedseen as elements of positive law, hence, property is not a natural right but a lawful creation derived from the authority of the state. Despite the legality of private property for Christian Fathers, the commons rights remain in the obligation to maintain the needy and in the limitation to private property.

\subsection{John Locke}

In the $17^{\text {th }}$ century, Locke developed a theory of property which has been of particular significance for contemporary IP. Normally, Locke's theory is defined as either a theory of natural law or a theory of labour (Drahos, 1996; Spinello \& Bottis, 2009). In this section, both positions are analysed to provide some criteria regarding Locke's influence for IP configuration and in the formulation of justifications for unequal distribution of property.

For Locke - following the Christian fathers - God has given the Earth in common to all humans for their preservation. "Whether we consider natural reason, which tells us that men (...) have a right to their preservation, and consequently to (...) things, as Nature affords for their subsistence" (Locke, 1982$, p. $17, \S 25)^{2}$. But, the right of property is originated in the person herself, "every man has a property in his own person." (p.18, §27). Humans as possessors of their own persons, are also owners of their labour which is a means to accomplish the 'divine' duty of self-preservation. Individuals through labour remove elements from the common state and exclude the others' common rights. An individual modifies nature by mixing it with something coming from him, hence, the ownership of labour's outcome is a reward for the 'painful' work-process in which the individual places a part of himself.

The analysis of the Lockean theory could be extended to IP; nature is modified not only through physical labour but also by intellectual labour which produces knowledge through discoveries and

\footnotetext{
1 Artistic works and books authorships were claimed by the signing of the creators (Vukmir, 1992, cited by May \& Sell, 2006).

2 The quotes in this section refer to Locke, J. (1982) unless another author is named.
} 
inventions. Perhaps, intellectual labour is not 'painful' but it requires effort which should be justly rewarded with its outcome. Similarly, the intellect seen as an individual's property is combined with nature for producing inventions which legitimise the appropriation of the commons. One can therefore argue that IP is a natural right derived from rationality which is a God-given capacity for selfpreservation.

Locke asserts some limits to property known as the "Lockean proviso" (Hettinger, 1989; Drahos, 1996; Spinello \& Bottis, 2009). The proviso states two conditions: 1) the sufficiency limitation which stipulates that any person's appropriation should not cause "any prejudice to any other man since there was still enough, and as good left" (p.21, §33);2) the spoilage limitation which says that a person can take possession of "as much as anyone can make use of (...) before it spoils, (...). Whatever is beyond this, is more than his share, and belongs to others" (p.20, §31). Regarding IP, according to Drahos (1996), the proviso is not accurate because knowledge does not spoil like land, or knowledge could be conceived as an infinite resource resulting from the endless ingenuity of humankind.

Locke's theory suggests that property is not for everyone, "[God] gave [the Earth] to the use of the industrious and rational; not to the fancy or covetousness of the quarrelsome and contentious" (p.21, $\$ 34$, emphasis added). Then, the non-industrious and non-rational men have not right to property nor commons usage, i.e., children, women and servants do not have right to property because they do not produce by themselves. They "could not cut the meat which their father or master had provided for them in common without assigning to everyone his peculiar part" (p.19, §29). In terms of IP, knowledge is not equally possessed for everyone; 'non-rational' subjects cannot own knowledge since they do not think nor produce by themselves. For Locke, the capacity for rationality application is not similar for all, e.g. among Europeans and American Indians their rationality and labour have different values and states which are expressed in their contrasting developments (§41-§43).

In conclusion, the Lockean 'man' could not be conceived without the connatural right to property as a reward for his 'painful' work which seeks for human preservation. Hence, Locke argues for an anthropocentric definition of nature in which all the creatures and resources are appropriable and exploitable for humankind's self-preservation. Locke has influenced IP theory based on the argument of labour - physical and intellectual - as a personal and appropriable process which enables and legitimates private property over the commons.

Locke's theory of property could be defined as an early justification for inequalities and commons privatisation. The existence of 'propertyless' people is explained by differences in labour and rationality among men. Any conflict resulting from labour and appropriation is solved for Locke (p.19, §29) through legislation settled by 'agreement or consent'. Thus, the increasing appropriation of the commons transgresses the Lockean proviso which is just understood as an ideal ethical guidance because, ultimately, property and its limits are defined by law. As the proviso does not strictly apply to knowledge IP ought to be limited by legislation for preventing excessive inequalities.

\subsection{G.W.F. Hegel}

IP in the $19^{\text {th }}$ century was already developed but Hegel deepened its legal and philosophical justification. A key point of the Hegelian argument is the assimilation of an unavoidable rational progress which includes the appropriation of knowledge. Hegel's theory is a conscious defence of IP through a precise definition of copyrights that protects creators and, at the same time, argues for the access to others' inventions for scientific innovation.

For Hegel $(1967, \text { pp. 35-36, } \S 33)^{3}$ property is the first phase of freedom conceived as the "absolute end" of world history, moreover, following Aristotle, he states that property is the "embodiment of personality" ( $\mathrm{p} .45, \S 51)$, a person expresses herself through her personality, subsequently, through her property. Property is not defined by "satisfaction of needs" ( $\mathrm{p} .235, \S 41 \mathrm{~A})$ but for the external expression of the subjectivity of personality as a means for the objectification of the person's will. The Hegelian definition of human loses its meaning without property, "[i]n his property a person exists for the first time as reason" (p.236, §41A). According to Hegel (p.236, §49A) humans as rational beings are "equal

3 The quotes in this section refer to Hegel (1967) unless another author is named. 
but only qua persons (...) [hence] everyone must have property", however, to claim for equality in terms of property "is an intellectualism all the more empty and superficial". The obtainment of ownership over something is a matter of physical and rational conditions which are different for every person.

Hegel provides a defence for the appropriation of an always increasing number of things, "[a]11 things may become man's property, because man is free will and consequently is absolute" (p.236, $\S 44 \mathrm{~A})$. Animals is one of the Hegelian examples as appropriable 'things' providing a philosophical validation for the current attempts to patent forms of life.

Regarding IP Hegel states that "[m]ental aptitudes, erudition, artistic skill, (...) inventions, and so forth, (...) [are] recognised as things" (pp.40-41, §43), therefore, they are susceptible to appropriation. The relationship between personality and property is more explicit considering inventions and artistic works (Drahos, 1996; Spinello \& Bottis, 2009). These works considered as external expressions of the mind belong to their creator but they are 'capital assets' which are reproducible by other subjects (pp.5456, §67-§69). Thus, Hegel defines copyrights with a double function: first, they enable the advancement of science and arts protecting creators from 'robbery'; second, copyright protection assures the access to inventions and artistic works to other people (pp.55-56, §69).

One might think that this is an argument in favour of knowledge commons (Drahos, 1996), however, Hegel is contrary to the commons. He criticises Plato's idea about the state as the propriety holder because it "violates the right of personality" (p.42, §46), on the contrary, the duty of the state is to protect ownership. Private property is more rational than common property since the individual will is expressed in personality through individual property. The commons are a threat for the individual self that affirms his identity recognising himself from others through the transfer of property. Commonality of resources represents an uncivilised stage of society for Hegel the state and private property are part of the objective progress of the self.

Consequently, Hegel's theory constitutes a defence of private property and inequality. The Hegelian critique to common property is a part of the argument which includes the thingification (reification) of inventions considered as 'capital assets'. It means that knowledge could be treated as an exchangeable commodity protected by legislation. "By the positioning of property laws in abstract objects, the personality, (...) gains a proprietary hold over the production and distribution of physical objects in undreamt ways" (Drahos, 1996, p.88). Moreover, the non-delimitation of what is appropriable is an 'open door' to the current process of over-patenting. The progressive appropriation of the commons is part of the self's rational development; thus, the rationality of private property could be the strongest argument in favour of proprietary knowledge as a rational outcome of science.

\subsection{Karl Marx}

Marx's theory is indispensable in order to comprehend the development of IP, intellectual labour, and accumulation of knowledge. The analysis presented in this part aims to highlight the social character of production through the division of labour. Even though, Marx does not present a particular reflection about IP, his theory is applicable to the subject providing ideas about commodification of knowledge and a possible alternative to the privative appropriation of knowledge.

Marx (2005a, p.98) - following Hegel - asserts that private property "is the material, sensuous expression of man's alienated life". However, Marx criticises private property as a pre-condition for the capitalist generation of surplus value. The origin of property is explained by a process of "primitive accumulation" deeply related to conquest, enslavement, and robbery (Marx, 1990). This process progressively separates the workers from the ownership of the means of production, causing a difference between a group of individuals who possess the means of production, the so-called bourgeoisie, and the proletariat whose only possession is labour power. Proletarians are 'forced' to sell their labour power considered as a commodity exchangeable by money (another commodity); this economic transaction gives to the buyer the 'right' to take possession of the labour's product.

Applying Marx's ideas to scientific production, one might suggest that knowledge is also appropriated to produce surplus value. Although, Marx remarks the materiality of labour power and production, labour is also intellectual and creative. A worker 'sells' his/her physical and intellectual labour power to produce technology and knowledge which are, latterly, sold as commodities in the market. Knowledge commodification is a consequence of Hegel's thingification of intellectual works. 
The product of scientific production, perceived as something external from the intellectual worker, is appropriable and exchangeable.

Knowledge is 'commoditised' as long as it is profitable, i.e. knowledge produced just for the sake of knowledge is not a commodity. This might explain why arts and some sciences, especially social sciences, are not encouraged with the same intensity as those considered lucrative. Similarly, profitability leads science to unexplored areas of research from which greater quantities of surplus value are obtainable, such as biotechnology, nanotechnology, pharmacology, among others.

Private property and commodification are complemented by division of labour, for Marx the always growing complexity of production creates a segmentation among workers with different responsibilities and skills. The labour of the individual is established from the start as collective labour, the individual worker needs other workers to produce and consume (Marx, 2005b). This situation also occurs within knowledge production with the emergence of a new intellectual division of labour which involves inequalities in the production and access to knowledge, same as happens in capitalist production.

Marx's theory is applicable to some extent to knowledge production. In this sense, despite the social character of scientific production, IP aims to protect the privative appropriation and accumulation of knowledge. Subsequently, IP legislation is intensively developed to protect the accumulation of knowledge in the form of inventions. The unequal distribution of knowledge could be explained by the restrictions imposed by IP to inventions and machinery as happens in capitalist production. The Marxist solution would be the abolition of private property, including IP, as the end of human oppression. Nonetheless, one might suggest that based on the social character of knowledge production IP could be configured in several forms not just a privative one founded on knowledge commodification.

\section{CONTEMPORARY INTELLECTUAL PROPERTY}

The internationalisation and standardisation of intellectual property rights (IPRs) were accomplished by the creation of the World Trade Organisation (WTO) and the approval of the Agreement on Trade Related aspects of Intellectual Property rights (TRIPs) in 1995. Henceforth, TRIPs attempted to set an equilibrium between protection of innovation, monopolies, and technological development. Although, the treaty has been criticised for defending the interests of developed countries and corporations, it has established the standard IPRs definitions ${ }^{4}$ such as:

- Intellectual property: IP "refers to creations of the mind: inventions; literary and artistic works; and symbols, names and images used in commerce" (WIPO, 2003, p.2). It has two categories: industrial property and copyright.

- Patent: It is applicable to "inventions, (...), in all fields of technology, provided that they are new, involve an inventive step and are capable of industrial application" (WTO, 1994, p.331). It confers the exclusive right for 20 years to prevent the use, production, and sale of the invention without the owner's consent.

- Trademarks: They cover signs, expressions or designs which identify a particular product. Trademarks confer the exclusive right to prevent the use of the sign without the owner's consent, their term is no less than seven years but it is indefinitely renewable.

- Copyrights: They protect all kind of works in the literary, scientific and artistic domains. Copyrights concede the exclusive right to authors to control, protect and reproduce their creations for the life of the author plus 50 or 70 years depending on the country.

TRIPs defined IPRs as private rights, philosophically speaking, they are based on the Lockean argument that property is for the 'industrious' and 'rational'. The inventor receives the reward for his/her invention through IPRs which guarantee profits and protection. Nevertheless, the right holder very often is not the inventor who is just a member of the intellectual labour division. Thus, the

${ }^{4}$ To find all the IPRs established by TRIPs see WTO (1994). 
researcher's knowledge is appropriated by the institution he/she is working for without the recompense of the patent. This contradiction to Locke's argument might be responded with another Locke's idea that workers by consent decide to work for a third party renouncing their property right. Contrariwise, one could criticise the argument, by reference to Marx, arguing that scientists have to 'sell' their intellectual labour power in order to subsist.

Originally, the objectives of IP were: a) invention protection; b) concession of monopolies, and c) industrial and social development. Accordingly, TRIPs tried to establish a balance between the three objectives considering the private and public interests (May \& Sell, 2006). Concerning the first objective, IPRs do protect inventions through the setting of restrictions inasmuch as the main threat for knowledge production is imitation which deprives the inventor from his/her reward. As a solution, strong IP legislation has been settled for preventing imitation and enhancing innovation. The unauthorised use of a patent is defined as a criminal offence against property called piracy which is punished with economic fines and even jail. The excessive protection might be explained by the Hegelian idea that property is an extension of personality, hence, any misuse of IPRs is not only a property violation but a violation to the owner's 'right of personality' that should be strictly punished.

In relation to the second objective, IP began with the grant of monopolies by Kings to guilds. Currently, the story is similar, IPRs are granted by the state as an 'exclusive right' to a person or corporation. Historically, guilds utilised the grants to control market and prices, a comparable situation has occurred in past decades in which 'patent cartels' ${ }^{5}$ have been created to control the markets applying unfair competition strategies (Dutfield, 2003). One might say that this is the most accomplished IP objective in the current times.

The third objective is supposedly accomplished by legal figures such as: "non-voluntary licenses", "exceptions" and "use without authorization of the right holder" which are recognised by TRIPs as mechanisms for technological transfer. Nevertheless, the same agreement stipulates multiple conditions for the application of those mechanisms. In reality, technological transfer is a complicated and tricky process: refusals for licensing patents; incomplete information provided in patents; lawsuits for unauthorised use of patents, are some of the difficulties presented. Accumulation and unequal distribution of knowledge is still a worldwide problem despite TRIPs; in the last 10 years, unequal patent applications are persisting as Fig. 1 demonstrates.

In 2004, just $2.8 \%$ of patent applications came from 'lower middle-income', and 'low-income' countries, and $97.2 \%$ from the 'higher-income' countries. Ten years later, the proportions are quite similar, $3.1 \%$ of patent applications took place in middle and low-income countries, whereas, $96.9 \%$ in 'upper middle' and 'high-income' countries. The only considerable change is the increase of applications in the 'upper middle-income' countries from $12.4 \%$ to $38.5 \%$ not because of technological transfer but of China's own investment in R\&D. The inequalities are such that in 2014 just China received 928,177 patent applications while countries like the United Kingdom received 23.040; Vietnam: 4447; Peru: 1287; Rwanda: 12 (WIPO, 2015, p.48-51). Thus, after more than 20 years of TRIPs approval technological dissemination is not a reality yet.

TRIPs allegedly attempted to establish an ambitious balance among market, innovation, and social development, however, the effort has failed insofar as the unbalance has favoured unequal distribution, monopolies, and market development. The disequilibrium affects in greater proportions to developing countries which do not have access to scientific production, but inversely, IPRs protect the interests of developed nations and corporations. Additionally, the agreement application is not homogenous since some of its dispositions are not compulsory for WTO members and, precisely, the 'flexible' application is recurrent in countries with more patent applications like the US and China.

\footnotetext{
5 A famous case is the "antibiotics cartel" formed by Pfizer, Cyanamid, Bristol, Upjohn and Squibb which controlled the tetracycline's price across thirteen countries from 1951 to 1961 (Braithwaite \& Drahos, 2002).
} 

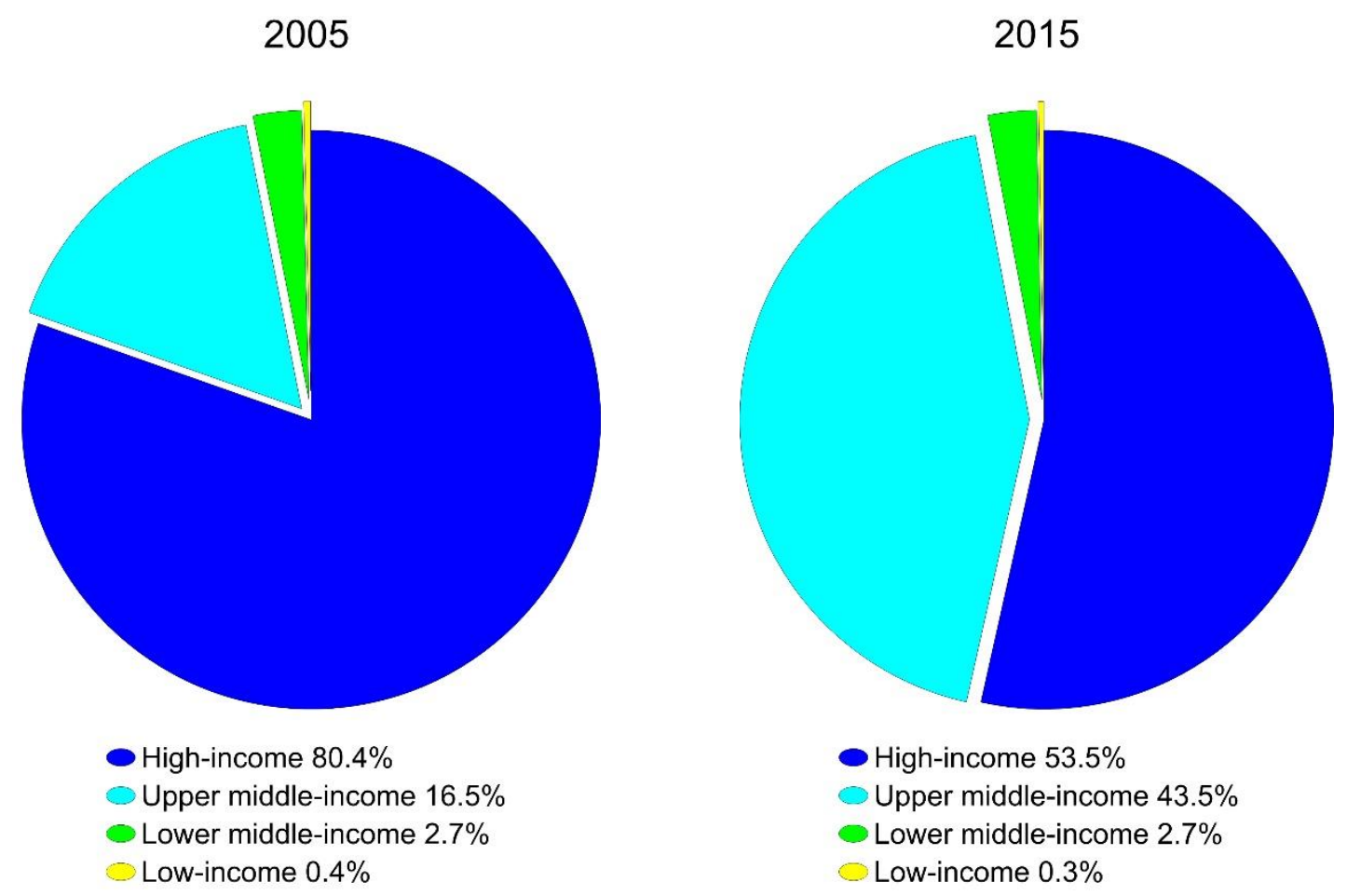

Figure 1. Patent application by countries income group from 2005 to 2015 (WIPO, 2016, p.23).

\subsection{Proprietary knowledge and over-patenting}

Contemporary IP privileges the patent holder's rights rather than the creator's rights. Frequently, it is argued that IPRs safeguard creations, however, they go beyond the invention and its creator. IP is conceived as a protection for the whole process of invention including: the investment, hiring of intellectual workforce, knowledge generation, equipment required, procedures, the invention characteristics, and even the trademark.

IP through proprietary knowledge creates scarcity for knowledge which normally is abundant and of fluid circulation. Scarcity is constructed to create 'rivalrousness' and competition, both necessary features for capitalist knowledge production (May \& Sell, 2006). Within market relations, the value of knowledge rises once it is conceived as a scarce resource which has to satisfy an ever-increasing demand. Knowledge scarcity is expressed in two ways: 1) by the restriction to the information which generates profits for the patent holder; 2) by the rivalry between patent holders whose competition, sometimes, is characterised by secrecy and over-patenting.

Then, how is scarcity created? In the case of material things their use is limited by possession. Consider the example of a pharmacologist who desires to produce accessible vaccines but is incapable due to the lack of the necessary equipment which is scarce and controlled. Whereas, in the case of knowledge, the scarcity is created through legal restrictions for its access. The idea to produce a vaccine is boundless, many individuals can have it, however, the knowledge required to create the vaccine is restricted by means of IPRs. The vaccine's formula is scarce for the pharmacologist as long as the patent holder controls its use and licensing.

Every time, more and more kinds of inventions are encapsulated as proprietary knowledge since the 'patentable subject matter' encompasses "any inventions, (...), in all fields of technology, provided that they are new, involve an inventive step and are capable of industrial application" (WTO, 1994, p.331). Though, there are some exceptions: a) inventions that could affect the environment, the life and health of humans, animals and plants; b) diagnostic, therapeutic and surgical methods for the treatment of humans or animals; c) plants, animals, and essentially biological processes to produce plants or animals. The problem lies in the non-compulsory character of the exceptions whose disparate application has created serious issues including attempts to patent genetic resources from humans, animals and plants. 
A broad scope for patentability has led to an 'over-patented' knowledge production in which inventions are protected by multiple patents for each single component ${ }^{6}$. Over-patenting hinders the access to an invention presented to the public as tacit knowledge ${ }^{7}$ which in turn is 'disjointed' in multiple patents. The access to that invention involves a fee payment for each patent which usually is not affordable for small producers and developing countries. Thus, patenting has been assumed as an essential factor of scientific production, once any creation is obtained it is registered and patented in the most countries as possible. Perhaps, one might add 'over-patenting' as a characteristic of current knowledge production in which the concession of IPRs continuously increases ${ }^{8}$.

The expansion of over-patented knowledge is the result of two factors: first, a predominant economic interest in knowledge production; secondly, the disparate application of TRIPs. The balance that TRIPs attempts to settle is expressed through time limits and exceptions to IPRs, nonetheless, exceptions and terms are discretionally applied by WTO members affecting in greater quantity to developing countries whose enforcement capacity against imitation and illegal appropriation is weaker. Subsequently, developed countries, corporations, and institutes have taken advantage of developing countries' conditions to appropriate their knowledge and genetic resources.

\subsection{Unrestricted 'Over-patenting': The Waorani Case}

Frequently, IP is assumed as a legal issue ignoring its economic, scientific, and bioethical implications. The over-patenting of knowledge has overtaken literary works and inventions, currently, genetic resources from animals, plants and humans have been 'enclosed' by IPRs. Even though there are treaties to settle limits for patentable subject matter such as TRIPs and the Convention for Biological Diversity (CBD) patenting has been applied as an unrestricted process. The controversial 'patenting of life' has focused the debate on the idea of considering a life form as either a human invention or a novel product.

The 'patenting of life' has benefited mostly to developed countries and corporations as a result of two processes: 1) their own investment and research in life sciences; 2) from biopiracy, i.e. the unconsented appropriation of genetic resources and traditional knowledge from developing countries and indigenous peoples (Sarma, 1999; Mgbeoji, 2006). The unfair exploitation derived from biopiracy essentially affects developing countries since weaker enforcement of IPRs and dissimilar application of IP legislation among countries. ${ }^{9}$

Some paradigmatic cases of 'life patenting' in the US are (CRG, 2000; Halbert, 2005; May \& Sell, 2006): in 1980, the first patented life form was the Pseudomonas putida a genetic modified strain of bacteria for oil-eating. In 1987, Harvard researchers were granted a patent for the "Harvard Oncomouse" - the first animal species considered as an invention - a genetically modified strain of mice susceptible to cancer by the insertion of a gen into its egg cells. In the case of human genetic resources, in 1976 a leukaemia patient had surgery at the University of California to remove his cancerous spleen. Later, the university patented a cell line called " $M o$ " extracted from the patient's spleen to produce proteins whose commercial benefit was estimated at over one billion dollars (CRG, 2000). Although, the patient demanded the return of his cells and body parts, the California Supreme Court decided that once the cells and body parts are removed from the body the patient loses the control over them.

There are hundred cases of biopiracy around the world (CRG, 2000; Utkarsh, 2001; Donovan, 2002; Barnett, 2006), just in Ecuador genetic resources from at least 16 animal and plant species have been patented by institutions from the US, Germany, Netherlands, Australia, Korea, Belgium, France, Israel, UK, and Iran (IEPI-SENESCYT, 2016). Furthermore, a controversial case in Ecuador involves

6 A mobile-phone encompasses more than 400 patents for its components: touchscreen, battery, camera, antenna, etc.

${ }^{7}$ It is "knowledge not available as a text and which may conveniently be regarded as residing in the heads of those working on a particular transformation process, or to be embodied in a particular organisational context" (Gibbons et al., 1997, p.168).

8 In 2008, there were 7.2 million patents in force, whereas, in 2014, there were 10.2 million (WIPO, 2015, p.31).

9 For example, the US has not ratified the CBD and allows patenting of living organisms, whereas, in countries such as Ecuador is illegal. 
the Waoranis - an Amazonian indigenous community - who were victims of biopiracy by the unconsented subtraction of blood samples. Between 1990 and 1991, two doctors visited the Waorani community as part of a medical brigade supported by the oil company Maxus. The doctors took blood samples from several Waoranis ${ }^{10}$ adducing that it was part of a medical research about their health problems and possible cures. Despite the researchers' compromise to come back with the results, they never returned and the Waoranis still do not know the results of the studies nor the location of their blood samples.

According to official reports (DPE, 2012; SENESCYT, 2012; CNBS; 2014), the DNA samples were sent by the Medicine School of Harvard to the Coriell Institute in the US in December 1991. The Waorani cell line was called 'GM 11776' and it was deposited in the Biorepository of the Institute. From 1994 to 2008, seven cell cultures and 36 DNA samples were distributed to 29 institutions in eight countries: Brazil, Canada, Germany, India, Italy, Japan, Singapore and the US; because of the sold samples at least 13 papers have been published until 2012.

The case became public in 2010 when the Waorani community presented a lawsuit to the National Ombudsperson against Coriell Institute. They were claiming for indigenous rights violation and for a part of the economic benefits obtained from their genetic resources. The Coriell Institute argued that it is a non-profit institution dedicated to research. However, the Waorani DNA was commercialised through the Institute's website for " 85 American dollars the cell cultures and 55 dollars the DNA samples" (CNBS, 2014, p.2). In 2012, the Ecuadorean government supported the Waorani community to sue the Coriell Institute for violation of indigenous rights. Surprisingly, the legal process was unfeasible due to the lack of federal legislation in the US against unconsented human DNA sampling. At the end, the Coriell Institute removed the DNA sample from its Biorepositories but it has not paid any fine nor has offered an apology to the Waoranis.

This case is a 'sample' of the unrestricted over-patenting of human, animal and plant genetic resources. Biopiracy is not just a legal issue, there are political, cultural, bioethical and scientific implications. In terms of medical research, several procedures and conventions were violated: The Nuremberg Code; the WMA Declaration of Helsinki (Ethical Principles for Medical Research involving Human subjects); the Universal Declaration on the Human Genome and Human Rights; the International Declaration on Human Genetic Data; and the United Nations Declaration on the rights of Indigenous Peoples. All these international instruments stipulate the requirement of the 'free, prior and informed consent' of the subject of research - especially from indigenous people - otherwise, the practice of any procedure is considered illegal and unscientific.

The underlying justification for 'life patenting' is that the organisms and genetic resources are patentable since they are not found in nature but in a laboratory setting. 'Reward for labour' and 'protection for innovation' are the arguments recalled, especially, when companies and institutes invest millions of dollars and spent years in researching the genetic resources obtained. Hence, 'overpatenting' leads knowledge production to unethical practices guided for economic interests, as a consequence of the unquestioned acceptance of IPRs in all fields.

But, is it legitimate to claim possession over forms of life? One might answer "yes it is!" Following Locke's labour theory, one would claim that researchers have mixed their effort and knowledge with nature gaining the natural right to reward. Similarly, one could quote Hegel who asserts that humans are free for taking possession of anything, therefore, forms of life considered as 'assets' are susceptible of appropriation. However, cases such as the Waoranis' provides several reasons to think about alternatives to an 'over-patented' knowledge production guided by profits rather than by scientific and social interests.

${ }^{10}$ Most of the Waoranis just spoke their native language, hence, the consent was tainted from the beginning. 


\section{KNOWLEDGE AS A COMMON GOOD}

"If I have seen further it is only by standing on the shoulders of giants."

(Newton, 1959, p.416)

Common goods are suggested as an alternative to proprietary knowledge. Typically, the commons refer to a recourse shared by a group of people which satisfies their needs through collective action and certain mechanisms of governance (David, 2001; Hess \& Ostrom, 2007; Boyle, 2008). The commons originally encompass natural resources such as forests, rivers, deep seas, air; in other words - following Roman law - resources upon which it is not possible to claim any ownership because they belong to a community or even to humankind. Thus, knowledge as a commons is expressed in its social character, knowledge is not developed nor owned individually and its production is socially distributed in terms of producers, composition, possession, and development.

Newton said to Robert Hooke in a letter "If I have seen further it is only by standing on the shoulders of giants." Indeed, one cannot 'see further' - research further - without ideas, theories, and principles from other persons. Knowledge does not 'come out of the blue', scientists are influenced by other scholars grounding their research on prior knowledge. The creativity process is reached only in interaction with others and relies on the structure of the commons (Drahos, 1996). Scientific production in its contexts of discovery and justification is influenced both by social and scientific factors coming from several actors. Scientific production cannot take place in isolation but in diverse contexts involving the assimilation of knowledge as a commons.

Knowledge might be considered as an infinite recourse whose commonality is enriched by its extended use and dissemination. According to Hess \& Ostrom (2007), knowledge is characterised as a 'nonsubtractive' resource whose use by a person does not affect the access to possible benefits by another person. Rivalry and exclusion are not proper features of knowledge they are created by IP. Any theory such as Quantum Mechanics might be used, researched, and modified simultaneously by several scientists without excluding one to the other; however, the access to the theory or to applied research outcomes could be restricted by IP through books, memberships, or lab equipment which are private goods.

A counterargument presented in favour of commons appropriation is based on the so-famous paper of Garrett Hardin The Tragedy of the Commons in which he states that "freedom in the commons brings ruin to all" (1968, p.1244). Hardin assumes that humans have the mind-set of the Homo Economicus, i.e. rational agents who are always looking for the maximisation of their gains. Consequently, individuals take possession as much as possible from the commons leading to their damage. The solutions suggested to prevent the "tragedy" are: private property, coercive laws, and taxes, in other words, mechanisms that restrict the access to the commons. Thus, private property is claimed following Hegel - as a rational device to 'restrain' the almost irrational 'accumulator instinct' which entails the destruction of the commons. Even though, private property is recognised as unfair for Hardin (1968, p.1247) "[i]njustice is preferable to total ruin".

Nevertheless, the tragedy does not apply accurately to 'knowledge commons', the more people possess and exploit knowledge the more it is developed, therefore, spoilage is not a problem for knowledge. On the contrary, the enclosure of knowledge represents a tragedy which restricts the access to information for profits generation. The scarcity created by IPRs inhibits the research of scientific resources that could improve the social welfare generating what Heller (1998) has called "the tragedy of the anti-commons" characterised by excessive IP legislation and over-patenting.

The tragedy of the anti-commons is represented by public domain (PD) the other face of the coin of IP. PD is formed by a) 'unpatentable' and 'uncopyrightable' items ${ }^{11}$; b) inventions and works whose legal protection has expired. This alternative enables transfer and access to knowledge since creations which 'fall' into PD are not subjected to any restriction. For that reason, some producers evade the

11 Unpatentable items are those that affect the public order, morality, health and life. Whereas, uncopyrightable items are theories, mathematical principles, laws of nature, etc. 
'fallen' through slight modifications of their inventions, e.g. some pharmaceutical companies modify the drugs' combinations to prevent the production of generic medicaments ${ }^{12}$.

Moreover, the ever-progressing IP legislation attempts to gradually reduce the scope of PD from which significant profits are obtainable. The Internet is the clearest case of broad access to knowledge through PD, every time more and more knowledge is available, but, at the same time, it is continuously limited by IP legislation, fees, and fares (Halbert, 2005). An alternative to this tragedy might be disclosure of knowledge by means of PD from which innovation is freely distributed undermining privative appropriation.

Nowadays, privative appropriation is regarded not only as the most rational but as the unique option for scientific production. IPRs are considered as the "end of history" for knowledge production; beyond IP, there is nothing more than tragedy, chaos, underdevelopment, and retrogress. Thus, the discussion of knowledge as a commons allows the suggestion of alternative approaches to IP. Knowledge production should not necessarily entail an individualised appropriation, it could take different forms such as: collective, communitarian, public, and private.

'Knowledge commons' presents solutions for contradictions generated by proprietary knowledge which affects innovation. I will consider three contradictions assuming as an example pharmaceutical research: a) between innovation and protection; b) among monopoly and competition; c) between competition and collaboration. Regarding the first, IP has been claimed as an innovation enhancer through the idea that protection and reward for inventiveness de facto stimulate scientific production. It may be true that producers are seeking for revenues, but excessive protection and over-patenting have a self-defeating effect. For example, new and better medicines are not produced because of excessive IPRs, a medicine must wait 20 years to be innovated and produced by alternative producers. As a result, knowledge production loses innovation for over-patented products whose alternative is to 'fall' in PD to be freely accessed.

In relation to the second contradiction, the argument is that IP favours competition through commercialisation. However, knowledge producers tend to accumulate patents and monopolise the market controlling prices and products, e. g. the medical patent cartels that control the production and prices of drugs. On the contrary, for Peritz (2012) knowledge disclosure benefits free competition by means of the access to patented inventions broadening the production and improving patents. Considering pharmaceutical research, cheaper and more effective medicines would be developed with a broader access to patented combinations.

The third contradiction is related to competition as a means for innovation. The problem relies on that competition is seen as a ferocious ${ }^{13}$ fight for economic benefits rather than for innovation. Nevertheless, knowledge production could be cooperative; for Hilty (2012), collaborative working is beneficial for competition because innovation does not 'happen in isolation'. Exchange, technology transfer, patent licensing are forms of cooperation which are not fully implemented as a consequence of the predominant economic mind-set in IPRs. Collaboration in pharmaceutical research would save millions of lives with accessible and effective drugs.

\subsection{An alternative knowledge production: the Colombian case}

A case within pharmaceutical research demonstrates how the contradictions of IP affect scientific production. The Colombian immunologist Manuel Patarroyo and his colleagues (1987) published his findings about the first synthetic vaccine against Malaria called 'SPF66' or "Vacuna Colombia contra la Malaria". It was the result of the production of synthetic peptides similar to those used by Plasmodium falciparum a malaria strain. The vaccine was tested on monkeys with $50 \%$ effectiveness; then it was applied to voluntaries in countries from Africa, Latin America, and Asia obtaining different results with an effectiveness average of 30\% (Fernández, 2014).

12 Developing countries such as South Africa, India, and Brazil have been sued by companies for the production of "generics" (Halbert, 2005).

13 Since the time of Thomas Edison competition has been judicialized in a process known as 'Patent Wars' (O’Hearn, 2000; Wise, 2014), just Edison was the protagonist of over 200 patents lawsuits (Shaver, 2012). 
In 1993, Patarroyo on behalf of Colombia donated the vaccine's patent to the World Health Organisation (WHO) for its production and distribution at low-costs. Unexpectedly, WHO was pressured by pharmaceutical companies to stop the production since the 'donation' was seen as a threat for the business. WHO ratified the agreement with Patarroyo in 1995, however, the vaccine ultimately was not produced, arguing for low effectiveness and bad results. The interesting fact is up until now a vaccine with better results has not been developed.

As Patarroyo claims, if we consider that around 500 million people are affected by malaria each year, $30 \%$ of that number is 150 million people who would recover from the disease every year (Holloway, 1996). Currently, Patarroyo is developing a vaccine with higher effectiveness but this time a consortium will produce and distribute it as a donation. The vaccine will be ready in two years after the research was cancelled for five years because of financial problems with the Colombian government and a court decision about animal mistreatment (Marrero, 2016).

As we can appreciate scientific production focused on profits affects not only knowledge but also human lives and social welfare. Proprietary knowledge creates exclusion from the benefits of science, thus, poverty, insalubrity, underdevelopment, and technological dependency are faces of over-patented knowledge. Patarroyo's vaccine is a good example that research does not necessarily have to seek profits and competition; on the contrary, science could be considered for collaboration and social welfare. Indeed, an alternative might be the suggestion and inclusion of alternative criteria for scientific production.

\subsection{Conclusion: The alternatives}

As a sort of conclusion, some of the alternatives suggested for proprietary knowledge are revised. Knowledge commons highlights the social character of scientific production: science and innovation do not happen in isolation but in diverse contexts involving several actors and interests. The predominant conception about IP is not absolute, the argument about the commons shows that the debate is still open-ended. IPRs as a legal construction are modifiable by means of the three aspects involved in scientific production: society, science, and the politico-economic system.

Proprietary knowledge is restricted information through the control of its application and production by the right holders. IPRs create the great contradiction of scarcity for knowledge which is tacitly possessed by few persons who can apply it to different ends. Precisely, knowledge as a 'common good' attempts to deconstruct the contradiction of scarcity through several mechanisms. Broadening PD, open access to scholarly journals, digital repositories and libraries, licensing information sharing, copy-left, 'Creative Commons' licenses, open-source software, and collaborative patent pools are some of the alternatives suggested to proprietary knowledge (Hess \& Ostrom, 2007).

IP as an element of the modes of knowledge production; is a structure conditioned by society, science, and the politico-economic system. As such, IP is modifiable, it is not a natural or rational right as in the Lockean and Hegelian conceptions. The current tendency is to extend the coverage and terms of IP, instead, it could be replaced by a predisposition to broaden PD for accessing knowledge. Alternative options might be the concession of compulsory licences to developing countries; the reduction of IPRs terms to enhance innovation through inventions released earlier to the PD. Likewise, patentable subject matter, exceptions, prohibitions, and objectives of IP are key aspects which ought to be debated by academia, society, and political institutions.

Today, scientific production is mostly based on criteria such as: applicability, marketability and profitability. Assimilating knowledge as a social activity allows the possibility to suggest alternative approaches to appraise research, e.g. social interest, sustainability, collaboration, availability, accessibility, and transferability. Moreover, knowledge commons is the opportunity to formulate diverse ownership definitions according to several contexts. Some of the definitions suggested for property over knowledge are (Hilty, 2012; Van Overwalle, 2012):

- Individual ownership: It represents the current private property over knowledge through intellectual property rights by individuals or institutions.

- Multiple ownership: There are a certain number of owners over inventions and creations. 
- Collaborative ownership: The owners shared the property for cooperative knowledge production, i.e. the aim is innovation and social interest rather than economic benefits.

- Communitarian ownership: This kind refers to property over traditional knowledge for indigenous peoples and original communities. Communitarian ownership is unalienable it cannot be privately appropriated.

- Public Ownership: This property responds to social interest and is administrated by public institutions. The access to this knowledge is open insofar as the research is for social benefit.

Knowledge commons does not mean free and open access to all the inventions protected. The openness is progressive and according to social interest, especially in fields such as health, pharmacology, agroindustry, biotechnology and strategic areas for social welfare. Thus, knowledge production could be regulated by various kinds of ownership which are adaptable to different settings. The principal aim of diverse IP definitions is to avert knowledge accumulation and unequal distribution. For this reason, the monopoly granted by IPRs ought to be gradually reduced and subjected to social interest. Undoubtedly, knowledge producers deserve the recovery of their investment and a reward for their efforts and creativeness, however, the compensation ought to be fair and limited because the end of research cannot be profit but innovation and social welfare.

Similarly, diverse notions about IP take advantage of scientific research. Cases such as the malaria vaccine demonstrate how the economic mind-set within IP obstructs the advancement of science. Whether knowledge is possessed in relation to social interest, most projects considered as non-profitable would not be overlooked as long as they benefit society. Knowledge commons might enhance innovation through revision and modification of restricted knowledge. A clear example is a study made by Andersen \& Rossi (2011) which shows that universities in the UK use all forms of IP for innovation and technology transfer. But, universities benefit in greater quantities from non-proprietary forms such as open-source and no-patented inventions. The data are shown in Table 1.

Table 1. Universities' benefits from participation in IP marketplaces (Andersen \& Rossi, 2011, p.716).

\begin{tabular}{lcccc}
\hline & Patents & Copyright & $\begin{array}{c}\text { Non-patented } \\
\text { innovations }\end{array}$ & Open source \\
\hline $\begin{array}{l}\text { Respondents in each IP } \\
\text { marketplace }\end{array}$ & 29 & 15 & 18 & 12 \\
$\begin{array}{l}\text { Types of benefits: } \\
\text { (i) Knowledge transfer }\end{array}$ & $\%$ & $\%$ & $\%$ & $\%$ \\
(ii) Knowledge creation & 31 & 67 & 72 & 83 \\
(iii) Awareness & 28 & 47 & 61 & 58 \\
(iv) Financial & 66 & 67 & 44 & 17 \\
\hline
\end{tabular}

The table show us that $58 \%$ of open source and $61 \%$ of non-patented innovations are utilised for knowledge creation, whereas, $31 \%$ of patents and $47 \%$ of copyrights are for producing knowledge, i.e. innovation within universities in the UK mostly rely on non-proprietary knowledge. A similar situation occurs with technology transfer that regularly depends on open knowledge, whereas, most of the proprietary knowledge is destined to financial ends rather than to innovation.

As May \& Sell state (2006, p.20) the "common use of knowledge across society is one of the key elements of a shared social existence". Knowledge is a social construction and as such should not be appropriated nor restricted for the benefit of a few. The commonality of knowledge production is expressed in: the intellectual division of labour; the revision of prior knowledge; the non-rivalry and non-scarcity of knowledge, and among other aspects. In conclusion, privative IP is not the 'end of history' for scientific production, precisely, the most important aspect for 'knowledge commons' is that reopens the door for a debate about an alternative knowledge production with different conceptions about IP. 


\section{ACKNOWLEDGEMENTS}

I am grateful to the London School of Economics and Political Science (LSE) for the approval of this article as my dissertation.

\section{BIBLIOGRAPHY}

Andersen B, Rossi F (2011). Intellectual Property governance and knowledge creation in UK universities. Economics of Innovation and New Technology 20(8):701-725

Aristotle (1992). The Politics, revised and re-presented by Trevor J. Saunders. London: Penguin Books

Barnett A (2006). The new piracy: how West 'steals' Africa's plants. The Guardian. Retrieved from https://www.theguardian.com/science/2006/aug/27/plants.theobserversuknewspages

Boyle J (2008). The public domain: Enclosing the commons of the mind. New Haven \& London: Yale University Press

Braithwaite J, Drahos P (2002). Intellectual property, corporate strategy, globalisation: TRIPs in context. Wisconsin International Law Journal 20(3):451-480

Buckland W (1963). A text-book of Roman law from Augustus to Justinian. Cambridge: Cambridge University Press

Carlyle AJ (1913). The theory of property in mediaeval theology. In: Gore C (Ed.), Property its duties and rights: Historically, philosophically and religiously regarded (pp. 117-132). London: MacMillan Publ. Co. Ltd

Comisión Nacional en Bioética en Salud [CNBS] (2014). Informe de la Comisión Nacional de Bioética en Salud de Ecuador respecto al caso de toma de muestras de ADN de Waorani. Quito. Retrieved from http://www.salud.gob.ec/wp-content/uploads/2016/03/Informe

Council for Responsible Genetics [CRG] (2000). Actionbioscience. Retrieved from DNA Patents Create Monopolies on Living Organisms: http://www.actionbioscience.org/genomics/crg.html

David P (1994). The evolution of intellectual property institutions. In: Aganbegyan A, Bogomolov O, Kaser MC (Eds.), System transformation: Eastern and western assessments. Proceedings of the Tenth Congress of the International Economic Association. I. London: MacMillan Publ. Co. Ltd

David P (2001). Tragedy of the public knowledge 'Commons'? Global science, intellectual property and the digital technological boomerang. MERIT-Infonomics Research Memorandum Serie (2001-003):1-36

David P (2008). The historical origins of 'Open Science': An essay on patronage, reputation and common agency contracting in the scientific revolution. Capitalism and Society 3(2):1-103

Defensoría del Pueblo de Ecuador [DPE] (2012). Recurso de revisión, resolución defensorial. Quito. Retrieved from http://repositorio.dpe.gob.ec/bitstream/39000/666/1/REV-024-DPE-2012.pdf

Donovan E (2002). Beans, beans, the patented fruit: The growing international conflict over the ownership of life. Loyola of Los Angeles International and Comparative Law Review, 25(1):117-142

Drahos P (1996). A philosophy of intellectual property. Aldeshot: Dartmouth Publishing

Dutfield G (2003). Intellectual property and the life sciences industries: A twentieth century history. Aldershot: Dartmouth Publishing

Fernández C (2014). El día que Patarroyo casi gana el nobel. El Tiempo. Retrieved from http://www.eltiempo.com/bocas/manuel-elkin-patarroyo-en-entrevista-con-revistabocas $/ 13748377$

Gibbons M, Limoges C, Nowotny H, Schwartzman S, Scott P, Trow M (1997). The new production of knowledge: The dynamics of science and research in contemporary societies. London: Sage 
Halbert D (2005). Resisting intellectual property. London \& New York: Routledge

Hardin G (1968). The tragedy of the commons. Science, New Series 162(3859):1243-1248

Hegel G (1967). Philosophy of right. London, Oxford \& New York: Oxford University Press

Heller M (1998). The tragedy of the anticommons: Property in the transition from Marx to Markets. Harvard Law Review 111(3):621-688

Hess C, Ostrom E (2007). Understanding knowledge as a commons, From theory to practice. Cambridge, Massachusetts: The MIT Press

Hettinger E (1989). Justifying intellectual property. Philosophy and Public Affairs 18:31-52

Hilty R (2012). Individual, multiple and collective ownership: what impact on competition? In: Rosén $\mathrm{J}$ (Ed.), Individualism and collectiveness in intellectual property law (pp. 3-44). Cheltenham \& Northampton: Edward Elgar

Hobhouse LT (1913). The historical evolution of property, in fact and in idea. In: Gore C (Ed.), Property its duties and rights: Historically, philosophically and religiously regarded (pp. 3-31). London: MacMillan Publ. Co. Ltd

Holloway M (1996). The man who would conquered malaria. Scientific American 275(6):52-56, doi:10.1038/scientificamerican1296-52

Instituto Ecuatoriano de Propiedad Intelectual [IEPI], Secretaría Nacional de Educación Superior, Ciencia, Tecnología e Innovación [SENESCYT] (2016). Primer informe sobre biopiratería en el Ecuador. Quito. Retrieved from http://www.eltelegrafo.com.ec/images/cms/ DocumentosPDF/2016/16-06-23-informe-de-biopirateria.pdf

Locke J (1982). Second treatise of government. Wheeling: Harlan Davidson Inc

Marrero A (2016). Manuel Elkin Patarroyo insiste en que en dos años tendrá y donará la vacuna contra la malaria. El Espectador. Retrieved from http://www.elespectador.com/noticias/ salud/manuel-elkin-patarroyo-insiste-dos-anos-tendra-y-donara-articulo-643777

Marx K (1990). Capital, a critique of political economy (Vol. I). London: Penguin Classics

Marx K (2005). Economic and philosophical manuscripts. In: McLellan D (Ed.). Karl Marx selected writings. New York: Oxford University Press

Marx K (2005). Grundisse. In: McLellan D (Ed.), Karl Marx selected writings. New York: Oxford University Press

May C, Sell S (2006). Intellectual property rights: A critical history. London: Lynne Rienner Publishers

Mgbeoji I (2006). Global biopiracy: Patents, plants and indigenous knowledge. Ithaca, NY: Cornell University Press

Newton I (1959). Letter from Sir Isaac Newton to Robert Hooke, February 5 1675. In: Turnbull H (Ed.), The correspondence of Isaac Newton: 1661-1675 (Vol. 1, pp. 416-418). New York: Cambridge University Press

O'Hearn T (2000). The reason for the patent war. Business Horizons 43(4):33-42 doi:https://doi.org/10.1016/S0007-6813(00)00069-0

Patarroyo M, Romero P, Torres M, Clavijo P, Moreno A, Martínez A, Rodriguez R, Guzman F, Cabezas E (1987). Induction of protective immunity against experimental infection with malaria using synthetic peptides. Nature 328(6131):629-632. doi:10.1038/328629a0

Peritz R (2012). The law and economics of progress: IP rights and competition policy. In: Rosén J (Ed.). Individualism and collectiveness in intellectual property law (pp. 45-54). Cheltenham \& Northampton: Edward Elgar

Rashdall H (1913). The philosophical theory of property. In: Gore C (Ed.), Property its duties and rights: Historically, philosophically and religiously regarded (pp. 34-64). London: MacMillan Publ. Co. Ltd

Sarma L (1999). Biopiracy: Twentieth century imperialism in the form of international agreements. Temple International and Comparative Law Journal 13:107-136 
Secretaría Nacional de Educación Superior, Ciencia, Tecnología e Innovación [SENESCYT] (2012). Informe preliminar técnico científico del caso "ADN de los Waorani". Quito, Ecuador

Shaver L (2012). Illuminating innovation: From patent racing to patent war. Washington and Lee Law Review 69:1891-1947, doi:http://dx.doi.org/10.2139/ssrn.1658643

Spinello R, Bottis M (2009). A defense of intellectual property right. Cheltenham: Edward Elgar Publ. Ltd

United Nations Environment Programme [UNEP] (1993). Convention on biological diversity [CBD]. Rio de Janeiro. Retrieved from https://www.cbd.int/convention/text/

Utkarsh G (2001). Patenting life? Biodiversity and intellectual property rights. Resonance (Febraury): 51-56. Retrieved from http://www.ias.ac.in/article/fulltext/reso/006/02/0051-0056

Van Overwalle G (2012). Individualism, collectivism and openness in patent law: from exclusion to inclusion through licensing. In: Rosén $\mathrm{J}$ (Ed.). Individualism and collectiveness in intellectual property law (pp. 71-114). Cheltenham \& Northampton: Edward Elgar

Wise J (2014). Patent wars: Affordable medicines versus intellectual property rights. British Medical Journal (348):g1533. doi:https://doi.org/10.1136/bmj.g1533

World Intellectual Property Organisation [WIPO] (1979). Berne convention for the protection of literary and artistic works. Retrieved from http://www.wipo.int/treaties/en/ text.jsp?file_id=283698

World Intellectual Property Organisation [WIPO] (1979). Paris convention for the protection of industrial property. Retrieved from http://www.wipo.int/wipolex/en/treaties/ text.jsp?file_id=287556

World Intellectual Property Organisation [WIPO] (2003). What is intellectual property? (450 (E)). Geneve: WIPO Publication

World Intellectual Property Organization [WIPO] (2015). WIPO IP facts and figures. Geneva. Retrieved from http://www.wipo.int/edocs/pubdocs/en/wipo_pub_943_2015.pdf

World Intellectual Property Organization (2016). World intellectual property indicators 2016. Geneva. Retrieved from http://www.wipo.int/edocs/pubdocs/en/wipo_pub_941_2016.pdf

World Trade Organisation [WTO] (1994). Annex 1c: Agreement on trade related aspects of intellectual property rights. Retrieved from https://www.wto.org/english/docs_e/legal_e/27trips.pdf 